\title{
Worth the paper that they are written on? Human rights and the environment in the law of England and Wales
}

\author{
Karen Morrow* \\ Professor of Environmental Law, Centre for Environmental Law and Policy (CEELP), School of Law, \\ Swansea University, Singleton Park, Swansea, UK
}

This paper considers recent domestic case law demonstrating developments of particular importance in pursuing environmental claims before the courts in England and Wales. It reflects on the evolution of mainstream human rights law, specifically the European Convention on Human Rights and the Human Rights Act in engaging with environmental claims before the courts. Further discussion focuses on the development of specifically environmental rights based regimes, in particular, the Aarhus Convention and the EU provisions that partially implement it and their application in domestic law.

Keywords: human rights, environment, procedure, ECHR, Aarhus Convention, judicial review, costs

\section{INTRODUCTION}

At the UN's 2002 World Summit on Sustainable Development, human rights were acknowledged as one of the factors underpinning sustainable development, with the Johannesburg Plan of Implementation stating that: 'Peace, security, stability and respect for human rights and fundamental freedoms, including the right to development, as well as respect for cultural diversity, are essential for achieving sustainable development and ensuring that sustainable development benefits all'. This political endorsement is in tandem with legal developments in related areas, not least in the well-established practice of human rights law latterly exhibiting an expansion of claims into the environmental sphere. ${ }^{2}$ While this development may generate anxiety amongst both legal ${ }^{3}$ and environmental commentators concerning the attempted assimilation of environmental concerns into an essentially anthropocentric regime, this has not prevented the emergence of an interesting body of case law which is

* Part of this paper formed a presentation at the Environment Section of the Society of Legal Scholars Conference in Keele 07 September 2009. I wish to thank the colleagues present for the valuable insights offered in discussion, though responsibility for any errors remains my own.

1. <http://www.un.org/esa/sustdev/documents/WSSD_POI_PD/English/POIToc.htm> para 5, accessed 04 September 2009.

2. See, for example, $\mathrm{C}$ Schall, 'Public Interest litigation concerning environmental matters before human rights courts: a promising future concept?' (2008) J Env L 417.

3. See, eg, A Boyle and M Anderson (eds), Human Rights Approaches to Environmental Protection (Clarendon Press, Oxford 1996); G Beck, 'Human rights adjudication under the ECHR between value pluralism and essential contestability' (2008) EHRLR 214. 
worthy of careful consideration in its own right. At the same time, as will become apparent, current legal coverage for environmental human rights claims is fragmented and partial, and the regimes that are in place in the area often overlap resulting in a complex web of potentially applicable law and nuanced multistranded cases. This paper will consider examples of developments in areas that are proving of particular importance in pursuing environmental claims before the UK courts, the evolution of mainstream human rights instruments to engage with environmental claims, and the development of specifically environmental rights regimes and their expression in recent developments in the domestic judicial review context.

Human rights may offer substantive and/or procedural protection ${ }^{4}$ to interests, though as the former category is particularly controversial in the environmental sphere, it is the latter less ambitious arena that has seen most development, not least in international law. In consequence the rights in question may more accurately be regarded as human rights that are contingent on the state of the environment rather than environmental human rights as such, though this type of nice distinction is of greater interest to the academic than to the average rights holder. Some commentators go so far as to argue that procedural rights actually offer more effective protection than would be provided by substantive rights, ${ }^{5}$ though arguably this is far from self-evident. It would be truer to say that in international environmental law, ${ }^{6}$ procedural rights currently offer more viable protection in the absence of agreement on what a substantive environmental human right should protect. This state of affairs is also predicated by the form and content of the applicable legal instruments.

Established instruments such as the 1950 European Convention on Human Rights $^{7}$ (ECHR) provide for both procedural rights and substantive rights. While the ECHR contains no rights pertaining directly to the environment (as indeed is to be expected of a document of its vintage), the European Court of Human Rights has adopted an innovative approach to its jurisprudence in general ${ }^{8}$ which has had important ramifications for its application to environmental matters. ${ }^{9}$ Chief among the procedural rights that have provided fruitful ground in this regard is Article 6 (the right to a fair hearing), and in the substantive rights category, Articles 8 (the right to respect for family and private life) and 1 to the First Protocol (the right to peaceful enjoyment of possessions) are of most significance for the purposes of this paper. Under these heads, environmental claims, have, on occasion been recognized as an adjunct to, or perhaps more accurately, contingent upon recognized substantive Convention rights, notably in landmark cases such as Lopez Ostra v Spain, ${ }^{10}$

4. See, for example, M Fitzmaurice, 'The European Convention on Human Rights and the human right to a clean environment', Contemporary Issues in International Environmental Law (Edward Elgar, Cheltenham 2009).

5. Ibid; T Hayward, Constitutional Environmental Rights (Oxford University Press, Oxford 2005).

6. Domestic constitutions also often provide for substantive environmental rights, though their content and application are often hugely controversial, see Hayward (n 5).

7. ECHR, <http://www.hri.org/docs/ECHR50.html\#C.Art6> accessed 18 August 2009.

8. See A Mowbray, 'The Creativity of the European Court of Human Rights' (2005) HRLR 57-79 for a brief consideration of the generally applicable 'living instrument' and 'practical and effective' doctrine approaches and specific discussion of what he terms the 'particularly sensitive field' of environment based case law, 69 .

9. Indeed, the ECHR's jurisprudence in this area has been influenced (though not bound by) more recent developments, notably the Aarhus Convention, see Schall (n 2) at 432.

10. (A/303-C) (1995) 20 EHRR 277. 
Guerra $v$ Italy ${ }^{11}$ and Fadeyeva $v$ Russia. ${ }^{12}$ That said, there are some significant limitations on the viability of the ECHR in environmental cases, not least being that the regime applies only to actual harm, ${ }^{13}$ risk is not covered and thus the protection offered on the ground is decidedly limited. Another significant factor curtailing the impact of the ECHR in environmental cases lies in the fact that the Convention offers only limited access to the courts for nongovernmental organizations (NGOs) raising public interest cases. While such groups can bring cases, and indeed in the environmental sphere they are frequent litigants on all legal stages, under the Convention they are subject to the general requirement imposed by Article 34 that substantive rights must have been violated in order to proceed. ${ }^{14}$ This can prove particularly problematic as such groups are often better positioned to invoke generally applicable procedural rights than substantive claims.

In addition to emerging coverage under established general human rights law regimes, a new generation of international law instruments is providing for specific (usually procedural) rights pertaining to the environment underpinning substantive law, such as those contained in the Espoo Convention and the Kiev Protocol ${ }^{15}$ on environmental impact assessment. This paper will focus on the more generally applicable regime, provided by the 1998 UNECE Convention on Access to Information, Public Participation in Decision-making and Access to Justice in Environmental Matters ${ }^{16}$ (the Aarhus Convention). The three pillars of the Aarhus Convention address access to information, participation and access to justice and, drawing heavily on international human rights law, ${ }^{17}$ offer potentially far reaching rights to both individuals and NGOs in respect of the environment. At the outset of this discussion, it should be noted that the Aarhus Convention enjoys a dual status in UK law which can make its effects somewhat uneven. On the one hand, as confirmed by the Court of Appeal in Morgan v Hinton Organics (Wessex) Ltd $^{18}$ (discussed below), as an international treaty to which the UK is a signatory but which has not been incorporated into domestic law, it is not applicable in the UK courts, though it can act as an aid to interpretation in cases where relevant domestic law is unclear. On the other hand, the fact that the EU is a signatory to the Convention (in contrast with the position of the $\mathrm{ECHR}^{19}$ ) is hugely significant. ${ }^{20}$ It has acted on its obligations in a number

11. (1998) 26 EHRR 357.

12. (2007) 45 EHRR 10.

13. See, for example, Dudgeon v UK (1982) 4 EHRR 149.

14. Though they can act in a representative capacity, see Asselbourg $v$ Luxembourg (App no 2912/95) ECHR 29 June 1999.

15. See, for example, K Morrow, 'Public Participation in the Assessment of the Effects of Certain Plans and Programmes on the Environment, Directive 2001/42/EC, the UNECE Espoo Convention and the Kiev Protocol' (2004) 4 Yearbook of European Environmental Law 49.

16. Convention on Access to Information, Public Participation in Decision-making and Access to Justice in Environmental Matters, <http://www.unece.org/env/pp/documents/ cep43e.pdf> accessed 19 August 2009.

17. Schall (n 2) 433.

18. [2009] EWCA Civ 107, [2009] P\&CR 4.

19. The EU is not a signatory of the ECHR, though the ECJ has frequently referred the Convention in its jurisprudence.

20. For discussion of the significance of Community law in this area, see R Gordon, 'Using EC law in environmental judicial review' (2007) JPL 826. 
of areas within its competence ${ }^{21}$ that are of interest for the purposes of this paper. The EU has legislated for Member States in both generally applicable provisions (notably Directive 2003/4/EC on public access to environmental information and Directive2003/35/EC providing for public participation in respect of the drawing up of certain plans and programmes relating to the environment) and by integrating specific provisions into regulatory regimes (such as Directive 2000/60/EC establishing a framework for Community action in the field of water policy and Directive 96/ 61 on integrated pollution prevention and control). In addition the EU has applied Aarhus provisions to some of its own institutional activities in Regulation (EC) No 1367/2006 of 6 September 2006 on the application of the provisions of the Aarhus Convention on Access to Information, Public Participation in Decision-making and Access to Justice in Environmental Matters to Community Institutions and Bodies. It has also applied the Aarhus provisions to some of its own institutional activities in Regulation (EC) 1367/2006 of the European Parliament and the Council of 6 September 2006 on the application of the provisions of the Aarhus Convention on Access to Information, Public Participations in Decision-making and Access to Justice in Environmental Matters to Community Institutions and Bodies. ${ }^{22}$ It is, however, significant that this regulation essentially allows a tight grip to be retained on standing before the European Courts. Under Article 230(4) of the Treaties, ${ }^{23}$ the requirement that a claimant demonstrate 'direct and individual concern' severely limits the potential for NGO actions and thus significantly curtails the potential of the third pillar of Aarhus. ${ }^{24}$ This is confirmed by the Court of First Instance decision on this point in Case T-91/07 WWF(UK) v Council of the European Union ${ }^{25} 2$ June 2008 and upheld on appeal in Case C-355/08 WWF(UK) v Council of the European Union. ${ }^{26}$ While the appeal ruling indicates that invoking procedural rights may, subject to the provisions of the legislation under consideration, be sufficient to indicate direct and individual concern and thus be the subject of litigation, this was not found to be the case here. Furthermore the court clearly stated its disapproval for what it viewed as the WWF's attempt to use procedural rights to challenge a substantive decision. ${ }^{27}$ The position of individuals is, however, generally better in regard to direct and individual concern. Furthermore as confirmed in Morgan, where EU law is in question, the rights guaranteed enjoy the usual status of Community law. ${ }^{28}$ To sum up, while the EU has made progress on information and participation, general access to justice has proved more problematic (though it is touched on in some of the specific regimes referred to), and a proposed directive $\mathrm{e}^{29}$ on this has not thus far been agreed. It is, however, clear then that a claimant's ability to access their Aarhus Convention rights in the UK courts will be dependent in part on whether (and to what extent) EU law applies to the context of the litigation.

21. For a general overview, see the European Convention, 'The Aarhus Convention' <http:// ec.europa.eu/environment/aarhus/\#legislation> accessed 01 September 2009.

22. [2006] OJ L264/13.

23. As demonstrated in Case T-585/93 Greenpeace v Commission [1995] ECR II-02205.

24. Schall (n 2) 440.

25. [2008] ECR II-00081.

26. [2009] Celex 60800355.

27. Ibid paras $44-48$.

28. As confirmed in Case C-239/03 Commission v France [2004] ECR I-09325.

29. 24 October 2003 Commission Proposal for a Directive of the European Parliament and of the Council on access to justice in environmental matters COM (2003) 624. 
The nature of environmental procedural rights litigation is such that it is normally pursued before the UK courts in public law, often in a claim for judicial review. Domestic administrative law offers protection to a range of procedural rights through the application of rules relating to procedural impropriety, principally through the concept of natural justice, specifically the right to a fair hearing and the rule against bias. Increasingly a broader concept of fairness is playing a role in decision-making in domestic judicial review, and it is frequently invoked in environmental cases. The cases raised by environmental rights claims are such that a complex web of argument is often employed, calling into play inventive combinations of ECHR rights, Aarhus rights, participation rights in EU law and domestic administrative law. This paper will now consider some of the most interesting recent litigation that has arisen with respect to environmental rights before the UK courts, subject to the proviso that, where multiple strands of argument have been employed, the case is categorized with reference to what appears dominant or particularly significant in the judgment in question.

\section{HUMAN RIGHTS CASES}

The Human Rights Act (HRA) 1998 imports ECHR rights into domestic law, allowing claimants to access them in the domestic courts rather than having to take cases before the European Court of Human Rights in Strasbourg. HRA cases also offer significant opportunities to reopen issues previously regarded as settled in domestic law, and cases from the broad environmental sphere have proved prominent in this. ${ }^{30}$ The case of Marcic $v$ Thames Water Utilities ${ }^{31}$ is particularly significant in this regard. The claimant's house and garden had been subject to repeated flooding over a period of years due to the increasing inadequacy of the local sewers for which Thames Water Utilities (TWU) had legal responsibility. TWU did not address the problem, being only one of many, and there was no realistic prospect of them doing so. Marcic had a statutory right of complaint under s18 of the Water Industry Act (WIA) 1991 but instead instituted civil proceedings in negligence, nuisance and under the rule in Rylands $v$ Fletcher, and proceedings for breach of statutory duty all of which were dismissed at first instance. He also argued successfully on the HRA (alleging breaches of Articles 6, 8 and 1 to the First Protocol of the ECHR). He was therefore awarded damages but only from 2 October 2002, when the HRA came into force. TWU appealed and Marcic cross-appealed. The Court of Appeal upheld the HRA element of the first instance decision and also found TWU liable in nuisance, entitling Marcic to damages for the duration of the interference, with massive financial implications for sewerage undertakers. The Court also, controversially, decided that the applicable statutory remedy was unsuitable to meet Marcic's needs, effectively allowing the common law and Convention rights to displace the established regulatory regime. The decision was overturned on appeal to the House of Lords. The Lords held that the statutory regime was best placed to determine the appropriate balance between someone in Marcic's position and those of TWU's other customers and that together with the supervisory judicial review jurisdiction of the courts this adequately protected Marcic's rights. Thus while Marcic saw the HRA facilitating interesting debate on environmental issues, the outcome ultimately

30. See K Morrow, 'The Rights Question: the Initial Impact of the Human Rights Act on Domestic Law relating to the Environment' (2005) JPL 1010 for a discussion of early litigation in this area.

31. [2003] UKHL 66, [2004] AC 42. 
restated the orthodox position that general legal provisions, including those relating to human rights, will not be allowed to displace specific regulatory law.

The relationship between human rights provisions, the common law and the WIA arose again in Dobson and Others $v$ Thames Water Utilities Limited. ${ }^{32}$ This case involved actions in private nuisance and under the HRA (in respect of Article 8 rights) by a mixed group of litigants in respect of problems caused by negligence ${ }^{33}$ at one of the defendant's sewage treatment works. Some enjoyed proprietary interests in the affected property and could thus claim in private nuisance; others lacked such an interest and were therefore only able to proceed seeking 'just satisfaction' under s8 (3) of the HRA. ${ }^{34}$ Several points tried as preliminary issues relating the relationship between damages awards at common law and under the HRA went to appeal. At first instance Ramsey $\mathbf{J}$ determined that damages awarded to those with a proprietary interest in private nuisance could (and usually would) be sufficient to deny further recovery under the HRA to those resident in the same property but lacking such an interest (for example children or lodgers). This reflects the orthodox understanding of private nuisance as connected to land rather than personal interests but arguably does not effectively consider whether the HRA offers additional protection to the latter contingent on interference with land. Both parties appealed. Waller LJ, giving judgment for the Court, first pointed out that the role of damages under the HRA was distinct from that in private law. ${ }^{35} \mathrm{He}$ then determined that an award in nuisance would be relevant to the considering whether to order damages under the HRA and this could only be determined at full trial. Dobson raised the further question of whether an award of what were termed 'top up' damages was applicable for those with a proprietary interest if they had not obtained 'just satisfaction' for a breach of Convention rights in nuisance. Ramsey $\mathbf{J}$ thought that this would be possible, but unusual; the Court of Appeal stated that it would be 'highly improbable if not inconceivable'. ${ }^{36}$ Thus Dobson leaves open the idea that human rights provisions may provide additional protection for those whose interests fall without the scope private nuisance, though on balance it appears unlikely that it will alter the position in practice of those whose rights are already protected by that branch of law. This is not a particularly satisfactory position as, while it alludes to the differing purposes of damages in human rights law and at common law, it fails to fully engage with the implications of this difference. As things stand, it appears that, for claimants with common law rights, human rights interests and redress for interference with them are virtually subsumed in the former (presumably as a component of amenity). On the other hand, for those who lack a proprietary interest, there remains a possibility of a discrete award for just satisfaction under the HRA. It is clear that this approach raises inconsistencies and requires fuller examination.

32. [2009] EWCA Civ 28, 2009 WL 6455.

33. In the absence of negligence, the case would fall under the Marcic ruling, para 38.

34. McKenna v British Aluminium [2002] Env LR 30; Chancery Division recognized that such claims were potentially arguable.

35. This was based on Lord Woolf CJ's approach in Anufrijeva $\mathrm{v}$ Southwark London Borough Council [2004] QB 1124, as approved by the House of Lords in R (Greenfield) $v$ Secretary of State for the Home Department [2005] 1 WLR 673, para 42.

36. Ibid para 50. 
Human rights claims also featured $R$ (Hardy) $v$ Milford Haven Port Authority, ${ }^{37}$ the latest challenge $\mathrm{e}^{38}$ to the introduction of a liquefied natural gas facility in Milford Haven and related works. ${ }^{39}$ The case focused on the Environmental Information Regulations (EIR) 2004 (SI 2004/3391) and Milford Haven Port Authority's refusal to disclose risk assessment information to the claimant. ${ }^{40}$ The Information Commissioner had ruled that the information should be released but the Port Authority disagreed, arguing that it was 'operational' rather than environmental, and lodged an appeal that was ongoing at the time of this renewed claim for judicial review. The claimant argued that there was an obligation to disclose based on Articles 2 (the right to life) and 8 of the ECHR. The claim failed as, amongst other things, in line with Marcic, the Court did not wish to displace the EIR regime. The ECHR claims failed, the Court deciding that the Convention rights in question did not require the State or the Port Authority to provide information as part of their positive obligations. ${ }^{41}$ Beatson $\mathrm{J}$ was persuaded that if information requirements arose, they were not freestanding but fell under Articles 2 and 8 and here were satisfied by the consideration of risk and public safety that had taken place in planning law (including hazardous substances consent) ${ }^{42}$ and when permission was initially refused for judicial review. ${ }^{43}$ Given that judicial review is always a remedy of last resort, the outcome in Hardy is not particularly surprising; what, however, does give cause for concern is the attitude to costs, discussed below.

A further example of a case heavily featuring the ECHR is Georgina Downs $v$ Secretary of States for Environment, Food and Rural Affairs. ${ }^{44}$ Downs, a wellknown campaigner for the safer use of pesticides, brought a claim for judicial review in respect of the Secretary of State's refusal to introduce additional precautionary measures. This decision went counter to the recommendations of the Royal Commission on Environmental Pollution (RCEP) but accorded with those of the Advisory Committee on Pesticides (ACP) on the matter. The claim focused on alleged breaches of Directive 91/414/EEC relating to risks to human health comprising and creating a disproportionate impact on the claimant's private life (Article 8 of the ECHR). Collins $\mathrm{J}$ found for the claimant, holding that the UK approach was based on a flawed model and in breach of the Directive. The Article 8 issue, though discussed at some length, was deemed not to add to the substance of the case. The decision was overturned on appeal. ${ }^{45}$ The Court of Appeal judgment raises several interesting issues, including its approach to challenges to official decisions in scientifically controversial areas

37. [2007] EWCA Civ 1403.

38. See M Edwards, ' $R$ (on the application of Hardy) $v$ Milford Haven Port Authority' Case Comment (2008) JPL 702.

39. After protests to the European Parliament, the European Commission promised to investigate related complaints on the pipeline issue, 'Gas Pipe Concerns to be Examined' <http:// news.bbc.co.uk/1/hi/wales/south_west/7152749.stm> (20 December 2007) accessed 01 September 2009.

40. Hardy v Pembrokeshire County Council [2006] EWCA 240 had attempted, unsuccessfully, to engage Article 2 of the ECHR in a judicial review of the environmental impact assessment process. The case failed on delay.

41. [2007] EWCA Civ 1403.

42. Ibid para 31.

43. $R$ (Hardy) v Milford Haven Port Authority [2007] EWHC 1883 Admin, [2008] JPL 702.

44. [2008] EWHC 2666 Admin, [2009] Env LR 19.

45. Downs $v$ Secretary of State for Environment, Food and Rural Affairs [2009] EWCA Civ 664; WL 1894645. 
(which characterize many environmental cases). Sullivan LJ, delivering the judgment of the Court, stated that, in the absence of scientific consensus, the claimant would have to establish a 'manifest error' in the impugned decision, which he characterized as a formidable obstacle ${ }^{46}$ that had not been surmounted here. This appears to be rooted in the broader judicial strategy of taking a 'hands off' approach to dealing with conflicting bodies of opinion in technical areas that they may be ill-equipped to evaluate. It is, however, arguably unsuited to addressing arguments based on risk, such as that in the instant case, which inevitably have difficulty in reaching the standard of 'solid evidence' invoked by the Court. ${ }^{47}$ In this case, the Court, somewhat harshly given the related views expressed by the RCEP and a minority of the $\mathrm{ACP}$, characterized the claimant's position as a mere difference of opinion with the Secretary of State, falling well short of what would be required to justify judicial intervention. The claimant's human rights arguments, though ultimately dismissed, were accorded close attention. Sullivan LJ clearly stated that compliance with the Directive was not in and of itself sufficient to address the human rights claim, adding: 'It is possible to envisage circumstances in which severe environmental pollution might infringe on individual complainants' Article 8 rights even though the state authorities had complied with all relevant legal requirements'. ${ }^{48}$ However he underlined, drawing on the European Court of Human Rights decision in Asselbourg v Luxembourg, ${ }^{49}$ that the possibility of harm to health or to the claimant's home life ${ }^{50}$ (more usually expressed as risk) would not provide a sufficient basis for an Article 8 claim: causation attributable either directly to state action or indirectly through failure to regulate a third party was required. This too is a formidable obstacle for claimants, as causation is a particularly vexed issue in environmental cases. The Court was also unconvinced that the interferences complained of would constitute the 'serious environmental pollution' required to invoke the ECHR. ${ }^{51}$ Interestingly, in light of the claimant's campaign agenda and the context of the claim which questioned the general efficacy of the legal regime for pesticides, the claim was regarded as individual rather than representative. This was contrasted with the Convention cases of Lopez Ostra v Spain, ${ }^{52}$ Guerra $v$ Italy $^{53}$ and Fadeyeva $v$ Russia ${ }^{54}$ which were characterized as involving pollution from particular sources affecting wide areas and numerous people and thus appropriate subjects for state action. This analysis could, however, also be applied to Downs' claim as the particular source of pollution could also affect others. In addition, it seems odd to preclude representative status to a claim that is argued as an exemplar of a nation-wide problem. The main problem for Downs actually seems to be that her claim was viewed as not so much arguing a problem with a specific application of the regulatory regime but rather questioned it as a whole. In this case, Sullivan LJ determined that the government had satisfied its obligation to put in place 'an effective regulatory framework' ${ }^{55}$ and that the law of nuisance provided

46. [2008] EWHC 2666 Admin para 76.

47. Ibid para 91 .

48. Ibid para 107.

49. (2912/95) 29 June 1999.

50. [2008] EWHC 2666 Admin para 109.

51. Ibid para 111.

52. See (n 10), above.

53. See (n 11), above.

54. See (n 12), above.

55. [2008] EWHC 2666 Admin para 112. 
redress for individuals. The latter is, however, problematic in that, while private nuisance could cover interference with use and enjoyment of land, it would not address personal injury, ${ }^{56}$ though a claim in public nuisance may be able to do so. ${ }^{57}$ Sullivan also invoked Convention jurisprudence on the need for state regulation of environmental impacts to strike a 'fair balance' between 'the competing interests of the individual and of the community as a whole' drawing on Hatton $v$ United Kingdom. ${ }^{58} \mathrm{He}$ referred to the Grand Chamber's reiteration of the subsidiary role of the Convention vis-à-vis national authorities in policy areas where there are legitimate differences of opinion. This approach suggests that there are real limits upon what may be achieved by individuals invoking their ECHR rights in the environmental sphere.

In summary then, while some aspects of the approach adopted by the Court to the human rights claim in UK law are encouraging in principle, and such claims are being given sufficient credence to warrant close judicial scrutiny, on balance, the protection of environmental interests remains contingent on breach of substantive Convention rights and the obstacles that claimants face remain considerable.

\section{INFORMATION CASES}

Edwards $v$ Environment Agency ${ }^{59}$ involved an appeal against a refusal to grant relief in a judicial review claim in respect of an integrated pollution prevention and control (IPPC) permit issued to a firm called Rugby Ltd, replacing its original licence, and raises information issues. Rugby wished to continue to operate its cement plant, but to alter its fuel to waste tyres. During protracted consultations, concerns arose about the public health implications of the proposed change and as a result the Environment Agency (EA) undertook further research, much of which (while based on material in the public domain) was not made public. In February 2003 the EA refused a request to make public the material in question on the basis that it was 'integral' to a decision yet to be taken which would be prejudiced by disclosure. The new permit was issued in August and a claim for judicial review was instituted in October 2003. The information was finally disclosed just before the hearing, and as a result the trial judge allowed the claimants to change the emphasis of their argument. The judge found that the EA had not breached EU law by its non-disclosure but that it had infringed the common law duty of fairness, preventing fully informed consultation. However he determined that this had not proved significant and refused to grant relief. In the Court of Appeal it was acknowledged that the non-disclosure gave cause for concern as the information was material to the permitting decision and the public should have been given the opportunity to comment on it. Non-disclosure was held to have left the public in ignorance of significant matters, breaching the common

56. Hunter v Canary Wharf [1997] AC 655.

57. In re Corby Group Litigation [2008] EWCA Civ 463, [2009] QB 335. The claimants succeeded in their action at first instance in Corby Group Litigation v Corby DC [2009] EWHC 1944 (TCC) though Corby District Council on 18 August 2009 announced their intention to appeal, see M Tran, 'Council to Appeal Against Toxic Waste Negligence Judgment' Guardian (London 19 August 2009) <http://www.guardian.co.uk/environment/2009/aug/19/corby-toxicwaste-birth-defects-appeal $>$ accessed 23 August 2009.

58. (2003) 37 EHRR 28, para 113.

59. [2006] EWCA Civ 877, [2007] Env LR 9. 
law duty of fairness. Nonetheless, the refusal to grant relief was upheld on a number of grounds, including the inability of the public to compel the EA to act under the IPPC regime. The House of Lords upheld the Court of Appeal decision in $R$ (Edwards and another) $v$ Environment Agency and Others ${ }^{60}$ basing their decision on the fact that provisions relating to providing information to the public under Directive 96/61 only applied to new installations or those undergoing a substantial change (which had been determined not to be the case here). The letter of the law was certainly satisfied in the Edwards litigation, though the same cannot be said for its spirit.

Broader concerns with information in environmental contexts in the UK are raised by the case of The Office of Communications $v$ The Information Commissioner, ${ }^{61}$ which concerns the operation of the EIR regime. ${ }^{62}$ The nature of the statute promised that litigation instituted under it would be rather technical. This seems to be borne out in this complex dispute concerning the extent of information disclosure required to satisfy the requirements of the public interest in disclosure in a query relating to the location and ownership of mobile phone base stations. While passing reference was made to s6 of the HRA and Article 1 to the First Protocol of the ECHR in argument, ${ }^{63}$ the case was determined with reference to the interpretation of what was necessary to determine the public interest under the EIR. A similar dispute on the interpretation of environmental information is evident in $R$ (Hardy) $v$ Milford Haven Port Authority, ${ }^{64}$ discussed above. Where information cases are concerned, thus far it seems that clear interpretation is a central concern and that questions of this nature can draw out the time and expense of accessing information (for both the individual litigant and the public sector) considerably. It is to be hoped that, as the EIR regime matures, at least some of these issues may be overcome as teething troubles, though it would appear that the regulations as they stand and the complex tri-part interplay of those seeking information, those whose information is sought and the regulators may well militate against this.

\section{PARTICIPATION}

While also technical in many respects, participation cases tend to raise issues of principle in a hugely visible way. This is very apparent in $R$ (Greenpeace Ltd) $v$ Secretary of State for Trade and Industry. ${ }^{65}$ This case involved a claim for judicial review concerning participation in a public consultation process on future government policy on nuclear power in the UK. Greenpeace sought a quashing order in respect of the government's 2006 decision to support nuclear new build, ${ }^{66}$ reversing policy from 2003.

60. [2008] UKHL 22, [2008] Env LR 34.

61. [2009] EWCA Civ 90, Times, 27 February 2009.

62. The Regulations are underpinned by the Code of Practice on the discharge of the obligations of public authorities under the Environmental Information Regulations 2004 (SI 2004: 3391) (2005) <http://www.ico.gov.uk/upload/documents/library/environmental_info_reg/ detailed_specialist_guides/environmental_information_regulations_code_of_practice.pdf $>$ accessed 24 August 2009.

63. [2009] EWCA Civ 90 para 46.

64. [2007] EWCA Civ 1403.

65. [2007] EWHC 311 Admin, [2007] Env LR 29.

66. DTI, The Energy Challenge: Energy Review Report $2006<$ http://www.berr.gov.uk/files/ file31890.pdf> accessed 24 August 2009. 
The decision followed a 12 -week consultation ${ }^{67}$ employing documentation that clearly delineated nuclear new build as a topic for consideration, reiterating the promise of ' ... the fullest public consultation' ${ }^{68}$ on the issue. Coverage of nuclear power in the documents and related public processes was very limited. The Greenpeace challenge was essentially founded on administrative law, specifically an alleged breach of legitimate expectation on the consultation process and the change of policy. It argued that the information provided in the process had been vague, inadequate and incomplete. ${ }^{69}$ Sullivan $\mathrm{J}$ (as he then was) determined that the issue was justiciable, despite its high-level policy content, as the contested promise had been made at the highest level. Significantly he added that the government's obligations with respect to consultation in the environmental sphere were now to be examined in light of the Aarhus Convention, ${ }^{70}$ an observation which did much to flag up its profile at an early stage. The case was, however, determined, as indeed it was argued, on domestic administrative law. Specific reference was made to the requirements for 'adequate' consultation outlined by Woolf MR $R v$ North \& East Devon Health Authority, ex parte Coughlan ${ }^{71}$ namely that it take place at a formative stage; have sufficient content to allow an 'intelligent response'; allow adequate time for a response and be 'conscientiously taken into account'. The Court also applied the general principle of fairness to consultation, referring to the Court of Appeal decision in Edwards (above). Sullivan J pointed out that, while consultation did not have to be perfect in order to escape judicial scrutiny, and decision-makers had broad discretion in this regard, the courts would intervene in cases where something had gone 'clearly and radically' wrong. ${ }^{72}$ In this case he was persuaded that the consultation had been unfair, being inadequate and lacking precision in key areas ${ }^{73}$ and (while not regarding this as conclusive) he also looked unfavourably on the use of the minimum consultation period in the circumstances. The notion of unfairness employed by Sullivan here is welcome, stressing as it does the needs and understanding of the general public ${ }^{74}$ (not only those of specialized NGOs ${ }^{75}$ ). He found the process to have been seriously flawed resulting in an outcome that was unforeseeable to participants and he therefore granted a declaration ${ }^{76}$ to this effect; significantly he refused the quashing order that the claimants sought. The former was a less contentious remedy in the context of separation of powers and the relationship between the courts and central government and is frequently employed in cases of this type.

67. The minimum period prescribed by the Cabinet Office for consultation exercises in the then applicable second version of its 'Code of Practice on Consultation', January 2004. This is reiterated in the current Department for Business, Enterprise and Regulatory Reform (BERR) Code of Practice on Consultation, $2008<\mathrm{http} / / /$ www.berr.gov.uk/files/file47158. pdf $>$ accessed 24 August 2009.

68. Executive Summary to the Consultation Document.

69. Much of the material, which formed the basis of the government's decision, was not available until after the consultation process closed.

70. [2007] EWHC 311 Admin para 49.

71. [2001] QB 213. The criteria drew on those employed in $R v$ Brent London Borough Council, ex parte Gunning [1985] LGR 168.

72. [2007] EWHC 311 Admin para 63.

73. Ibid eg, paras $67,68,74$ and 79 .

74. Ibid para 113 .

75. See Morrow (n 15) above.

76. [2007] EWHC 311 Admin para 120. 
The case of Bard Campaign, David Bliss $v$ Secretary of State for Communities and Local Government ${ }^{77}$ also concerns participation in a consultation exercise and raises many issues touched upon in Greenpeace, this time in the context of the land use planning system. The case focuses a number of challenges to the contentious shortlisting of candidate sites for the government's eco-towns initiative. Bard's case involved a multistranded attack on the consultation process alleging breaches of the common law, the Aarhus Convention, the Code of Practice on Consultation and the Strategic Environmental Assessment (SEA) Directive. While the claims failed on all points. Walker J's judgment raised some interesting issues on the current status of the variety of consultation rights in UK law. Insofar as the common law was concerned, Walker $\mathrm{J}$ took the view that the Coughlan case provided the key test for adequate consultation, ${ }^{78}$ though he added a single additional qualification (accepted by the Secretary of State ${ }^{79}$ ) based on a narrow interpretation of Sullivan J's view of fairness in the Greenpeace case. This concerned situations where doubt arose as to the status of a document as a consultation paper or an issues paper. To qualify as the former, the test was whether consultees, taking the document at face value, could reasonably foresee that their responses would be considered in determining issues of principle. ${ }^{80}$ Walker $\mathrm{J}$ regarded most of the Coughlan criteria as fairly easily satisfied on the facts, and after close consideration of those he deemed problematic concluded that all had in fact been satisfied. He determined that the Aarhus and SEA claims were not relevant to the case in hand, though it is worth mentioning in respect of the former that the Secretary of State, somewhat worryingly, disputed the relevance of the Convention. ${ }^{81}$ Other issues, including whether the Code of Practice on Consultation had been complied with, were more complex but were eventually resolved in favour of the Secretary of State. This option was open to the Court in view of the multistaged nature of the consultation exercise under consideration allowing controversial issues (for example on alternative sites $^{82}$ ) to be examined in detail later in the process.

Participation threw up another interesting case, this time under the IPPC regime in $R$ (Lewes District Friends of the Earth) v East Sussex $C C .^{83}$ In this case FoE sought to appeal the refusal of a claim for judicial review to overturn a grant of planning permission for an energy recovery facility. Their argument centred on the fact that the permission had been granted in part on reliance on an IPPC permit that was subsequently quashed ${ }^{84}$ as unlawful. The application had been subject to consultation under the EIA, PPC and planning regimes. Sullivan J (as he then was) in dismissing the appeal stated that, while the outcome of the decision-making processes may have disappointed objectors, the decision could not be regarded as unreasonable. He added that when the reissued PPC permit was consulted on there would be further opportunity to scrutinize any legal flaws in the EA's position and the plant would only be legally operable once the permit was in place. ${ }^{85}$ However, as Sullivan J noted, work on the site had already begun by the time that he heard the case and this

77. [2009] EWHC 308 Admin, 2009 WL 648836.

78. Ibid para 64.

79. Ibid para 74 .

80. Ibid.

81. Ibid para 81 .

82. Ibid para 117 et seq.

83. [2008] EWHC 1981 Admin, [2009] Env LR 11.

84. On technical grounds relating to the adequacy of the reasons given by the EA.

85. Ibid para 38 . 
being the case, given the outcome in previous cases, ${ }^{86}$ in such circumstances further claims are likely to prove fruitless in real terms.

\section{ACCESS TO JUSTICE}

The UK Government reported in $2008,{ }^{87}$ following a consultation exercise, on its implementation of the Aarhus Convention to date. The report, while showing a considerable amount of legislative action in response to Aarhus and the EC laws promoting its implementation, is rather more opaque in its coverage of problematic areas. This is particularly the case with respect to implementation of aspects of the particularly challenging third pillar of the Convention, ${ }^{88}$ notably Article 9. Difficulties have been identified in a number of areas by the $\mathrm{EC}^{89}$ and several domestic inquires, notably the Liberty Report of the Working Group on Facilitating Public Interest Litigation (FPIL) 'Litigating the Public Interest', 90 the DEFRA funded Environmental Law Foundation led study: 'Environmental Justice: a report by the Environmental Justice Project' (EJP), ${ }^{91}$ and the Report of the Working Group on Access to Environmental Justice 'Ensuring Access to Environmental Justice in England and Wales' (the Sullivan Report). ${ }^{92}$ Key problematic areas in access to justice often include standing and issues related to the cost of litigation.

\subsection{Standing}

Claims by legal or natural persons in their own right pursuing Aarhus rights are fairly unproblematic in principle in UK law and will be touched upon only briefly here. Such litigation most frequently takes the form of judicial review as third parties lack statutory rights of appeal in command and control regulatory regimes that dominate this area. This does not generally pose difficulties as the courts tend to be fairly generous where standing is concerned in environmental cases. This is amply demonstrated in cases such as $R v$ Her Majesty's Inspectorate of Pollution (HMIP) and the Minister of Agriculture, Fisheries and Food, ex parte Greenpeace ${ }^{93}$ and $R v$ Secretary of State for Foreign and Commonwealth Affairs, ex parte World Development

86. See, eg, $R v$ Swale BC, ex $p$ RSPB [1991] 1 PLR 6; $R$ (England) $v$ Tower Hamlets LBC [2006] EWCA Civ 1742, (see (n 87), below).

87. Department of Environment, Food and Rural Affairs (DEFRA) 2008 UK Aarhus Convention Implementation Report 2008 <http://www.defra.gov.uk/ENVIRONMENT/internat/aarhus/ pdf/compliance-report.pdf $>$ accessed 24 August 2009.

88. See, for example, the UNECE Meeting of the Parties to the Convention on Access to Information, Public Participation in Decision-Making and Access to Justice in Environmental Matters Synthesis Report of the Status of the Implementation of the Convention, 2008 ECE/ MP.PP/2008/4 <http://www.unece.org/env/documents/2008/pp/mop3/ece_mp_pp_2008_4_e. pdf> accessed 24 August 2009.

89. European Commission Measures on Access to Justice in Environmental Matters (Article 9 (3)) (2007) <http://ec.europa.eu/environment/aarhus/study_access.htm> accessed 04 September 2009.

90. (2006) <http://www.liberty-human-rights.org.uk/publications/6-reports/litigating-thepublic-interest.pdf $>$ accessed 04 September 2009.

91. <http://www.ukela.org/content/doclib/116.pdf> accessed 04 September 2009.

92. (2008) <http://www.wwf.org.uk/filelibrary/pdf/justice_report_08.pdf> accessed 04 September 2009.

93. [1994] 2 CMLR 548. 
Movement. ${ }^{94}$ These NGO-initiated cases demonstrate the UK courts' rapidly evolving approach to standing in public interest environmental litigation. While in the Greenpeace case, standing was accorded to the NGO in part due to its expertise, the fact that it has a local membership that stood to be affected by the decision in question was also a determining factor. In the WDM case, however, there was no party in the UK that stood to be directly affected by the decision. The WDM was accorded standing as, had the Court decided otherwise, it would not have been possible to bring a significant legal issue before the courts. This stands in marked contrast to the much criticized decision in $R v$ Secretary of State for the Environment, ex parte Rose Theatre Trust Co Ltd ${ }^{95}$ which created the legal anathema of an unreviewable decision only shortly before.

\subsection{Cost}

Although access to the courts in the UK is rarely legally problematic, financially access can be much more challenging, with the cost of bringing proceedings proving a most significant fetter on public admittance to the courts. While the provision of rights in the environmental sphere is all very laudable, Article 9(4) of the Aarhus Convention recognizes that their significance is likely marginal if the cost ${ }^{96}$ of bringing proceedings is prohibitive. The Convention obliges parties to: ' $\ldots$ provide adequate and effective remedies, including injunctive relief as appropriate, and be fair, equitable and timely and not prohibitively expensive'. The UK Aarhus implementation report rightly points out that court fees (at $£ 30$ to apply for permission and $£ 180$ to bring a substantive claim before the Administrative Court ${ }^{97}$ ) are low for the claim for judicial review. At the same time, it rather disingenuously avoids the issue of the legal costs of bringing a case, which routinely run into tens of thousands of pounds ensuring that only the wealthy may enjoy self-funded access to the courts.

In environmental cases, potential costs are often further ratcheted up by the normal requirement of a cross undertaking in damages in respect of injunctive relief which is often of crucial importance in this context. The funding issue is made more problematic in UK law by the fact that, while the Civil Procedure Rules give the courts considerable discretion with regard to costs, as a general rule, if a claimant loses a case, they will be eligible not only for their own legal costs but also for those of the defendant. This approach has been described as worst practice and a 'significant barrier to access to justice'. ${ }^{98}$ (The normal position where the claimant is legally aided is somewhat different in that, generally, the defendant's recovery of costs is limited to acknowledgement of service. There are, however (albeit rare), exceptions to this approach as in $R$ (Hardy) v Milford Haven Port Authority, ${ }^{99}$ where Beatson J granted the defendant full costs on the basis that the issues had been raised and the documents in question sought without success before the courts on three previous

94. [1995] 1 WLR 386.

95. [1990] 1 QB 504.

96. In addition to standing, cost is generally acknowledged as the factor presenting the greatest obstacle to environmental public interest litigations, see, for example, JE Bonine: Best Practices - Access to Justice (Agenda for Public Interest Law Reform) <http://www.accessinitiative. org/resource/best-practices\%E2\%80\%94access-justice\%EF\%80\%AA>.

97. Ibid 27.

98. Ibid 22.

99. [2007] EWCA Civ 1403. 
occasions. ${ }^{100}$ ) So litigation is, at best, a costly business and at worst represents a risk beyond all reason, ${ }^{101}$ with the prospect of substantial costs having significant potential to dissuade potential claimants from taking recourse to the courts.

The DEFRA report points to the availability of public funding (formerly known as civil legal aid) in this area now extending to public interest cases ${ }^{102}$ (indeed the applicable guidance now makes specific reference to the Aarhus Convention ${ }^{103}$ ). However, no mention is made of the fact that, even where a claimant is potentially eligible (which will be in a minority of cases as only the very poor will qualify) public funding in general, and civil legal aid in particular is under such immense pressure that it is unable to keep pace with increased rights of access to the courts, ${ }^{104}$ not least those under the Aarhus Convention. ${ }^{105}$

The courts themselves have attempted to use their discretion with respect to costs to facilitate public interest litigation more generally, through the adoption of Protective Costs Orders (PCOs). The Court of Appeal had the opportunity to reconsider costs, ${ }^{106}$ and PCOs in a public interest context in the leading case of $R$ (Corner House Research) $v$ Secretary of State for Trade and Industry. ${ }^{107}$ In this case the purpose of a PCO was stated as being: ' ... to enable the applicant to present its case to the court with a reasonably competent advocate without being exposed to such serious financial risks that would deter it from advancing a case of general public importance $\ldots .{ }^{108}$ In principle, PCOs offer a viable means to facilitate public interest litigation by capping the amount that claimants will have to pay to cover the defendant's $\operatorname{costs}^{109}$ should their claim ultimately fail, which, on the face of things, sits well with the Aarhus requirements. In practice, as the following discussion will demonstrate, PCOs are a less viable mechanism for addressing the Aarhus obligations than they might at first appear. ${ }^{110}$

The Cornerhouse case concerned a public interest action by an NGO against the DTI in respect of failure to consult on measures to tackle bribery and corruption. Brooke LJ, giving judgment, identified the requirements to be satisfied in imposing a PCO:

1. The issues raised are of general public importance;

2. The public interest requires their resolution;

3. The claimant has no private interest in the outcome;

4. Having regard to the financial resources of the parties, it is fair and just to make an order;

5. If the order were not made, the claimant would probably discontinue the litigation and would be acting reasonably in doing so.

100. Ibid para 46.

101. Bonine (n 96) 20.

102. Ibid 28.

103. See the Legal Services Commission Funding Code Criteria <http://legalservices.gov.uk>.

104. For example, under the HRA/ECHR regime. S2.4.

105. As noted by the Court of Appeal in $R$ (Burkett) $v$ Hammersmith (No.2) [2004] EWCA Civ 1342, [2005] CP Rep 11.

106. PCOs were originally considered and very restrictively formulated in $R v$ Lord Chancellor, ex p Child Poverty Action Group [1999] 1 WLR 347.

107. [2005] EWCA Civ 192, [2005] 1 WLR 2600.

108. Ibid para 76.

109. As a general rule the losing party will be expected to pay the winning party's costs, r.43(3)

(2)(a) of the Civil Procedure Rules.

110. See (n 92) paras 41-55 and Appendix 3. 
The first ${ }^{111}$ and especially the third of these requirements can, however, prove particularly problematic in an environmental context. The latter has caused problems more generally since its inception, notably in $R$ (Goodson) $v$ Bedfordshire and Luton Coroner, ${ }^{112}$ in which it was pointed out that, to take it to its logical conclusion, it would preclude individuals with a sufficient interest to bring a claim for judicial review from being awarded a PCO, leaving action solely the preserve of NGOs. Brooke LJ himself has subsequently publicly expressed second thoughts on this issue in a lecture to the Law Society. ${ }^{113}$ The severity of the Goodson approach to private interest on public interest litigation, in general, has however been remarked upon and indeed tempered, albeit obiter, in subsequent case law promoting a more flexible approach, notably, $R$ (England) $v$ Tower Hamlets $L B C,{ }^{114}$ (see below); $R$ (Bullmore) $v$ West Hertfordshire Hospitals NHS Trust ${ }^{115}$ and Morgan v Hinton Organics (Wessex) $L t d^{116}$ (see below).

A further significant consideration relating to costs raised by the Cornerhouse approach relates to its commercial viability. In the case the Court stated that pro bono representation would strengthen a claim for a PCO. In reality relatively few cases proceed on this basis and relying on the altruism of some practitioners is hardly a sufficient basis to deal with this issue. The Court also limited the costs recoverable for successful claimants ${ }^{117}$ to solicitor's fees and fees for a single junior advocate. This relatively low level of cost provision has been much criticized ${ }^{118}$ as environmental cases are often of such complexity that it would be unlikely to reflect the resources actually required to litigate them, ${ }^{119}$ and may well serve to discourage mainstream legal firms from engaging with such cases and claimants from approaching them. ${ }^{120}$ The same may also be said for $R$ (Buglife $v$ The Invertebrate Conservation Trust) v Thurrock Thames Gateway Development Corporation ${ }^{121}$ (see below). Here one of the issues that the Court considered was the role of conditional fee arrangements (CFAs) as a source of funding in this regard (they are not viable if a PCO is in place). The Court's approach in common with that adopted toward PCOs is to keep the amounts in question modest, and thus limits their potential to make much of an impact on the funding impasse. ${ }^{122}$ These factors make public interest litigation at best commercially unappealing and create the very real possibility that public interest litigation of all classes will be confirmed as a thoroughly marginal activity.

In $R$ (Burkett) v Hammersmith (No.2) ${ }^{123}$ the Court of Appeal was called upon to deal specifically with participation in the context of the Aarhus Convention. The case concerned a judicial review in respect of a grant of planning permission: outline

111. See (n 92), above.

112. [2005] EWCA Civ 1172, [2006] CP Rep 6.

113. At a lecture to the Law Society, see 'Current Topics' JPL [2006] 1767-1773 at 1768.

114. [2006] EWCA Civ 1742.

115. [2007] EWCA Civ 609, [2007] Cost LR 844.

116. [2009] EWCA Civ 107, [2009] 2 P\&CR 4.

117. [2005] EWCA Civ 192 para 76.

118. See (n 92) above.

119. A view evidently shared by the Working Group on Facilitating Public Interest Litigation, which recommended that it be deemed irrelevant (n 90).

120. This would seem to be borne out by the 'Environmental Justice: a Report by the Environmental Justice Project' at www.defra.gov,uk/environment/justice/index.htm.

121. [2008] EWCA 1209, [2008] EWCA 1209, [2009] Env LR 18.

122. Ibid para 6.

123. [2004] EWCA Civ 1342, [2005] CP Rep 11. 
permission was granted in September 1999, full permission in May 2000 and a judicial review initiated in April 2000. The claimant was an individual, fully funded by the LSC, and the defendant was a local authority. Leave was refused at first instance and in the Court of Appeal on delay, but the claimant was successful on this point in the House of Lords and their Lordships ordered that the Council pay her costs for the appeal proceedings. When the substantive case was remitted to the High Court, Newman J ordered that the authority's costs at the application stage be set off against those that it had been ordered to pay in the House of Lords. The claimant sought a judicial review of this decision, arguing that the costs awarded by the Lords belonged to the LSC and could not be used to set off costs ordered against her by the Court. The appeal was rejected. While Brooke LJ recognized that the LSC's funds for civil litigation are under severe strain, he pointed out that local authorities experience similar pressures. $^{124}$ (In this case, the developer, which stood to benefit from the impugned planning permission, actually took a full and active role in the proceedings and its crack legal team prepared most of the evidence that was placed before the courts by the Council, ${ }^{125}$ an arrangement that is not uncommon in this type of case.) In Burkett, costs were sufficiently high to require the LSC to issue the claimant with an additional funding certificate for the proceedings before the House of Lords. ${ }^{126}$ In total, the claimant's costs were reckoned at $£ 135,000$, with Newman J's offset at $£ 35,000$. The actual amount due to the claimant's solicitors (even at the relatively low statutory fee scales for legal aid) was calculated at $£ 70,000$, and they stood to lose out to the tune of $£ 35,000$ as a result of Newman J's order. The Lords expressed considerable concern about the sums involved in the claimant's case, noting that: ' $\ldots$ if the figures revealed by this case were in any sense typical of the costs reasonably incurred in litigating such cases up to the highest level, very serious questions would be raised as to the possibility of ever living up to the Aarhus ideals within our present legal system'. ${ }^{127,128}$ While the costs involved in Bur$k e t t$ were indeed substantial, despite the Lords' reservations and criticisms of the claimant's legal team's preparation of the case, they do not seem to be overly high for a case that ultimately involved such protracted proceedings. This aspect of funding goes to equality of arms (or, more precisely, the lack thereof) which is almost inevitably at issue in environmental cases involving, on the one side individuals and/or NGOs, and on the other public authorities and often substantial commercial undertakings. The dominant approach is likely to mean that even publicly funded private interest litigants will be unable to present their case to full advantage and this is problematic in Aarhus terms.

In Burkett the Law Lords further alluded to problems of the cost-effectiveness or otherwise of litigation as a response to environmental disputes, noting the availability of other avenues of redress. ${ }^{129}$ However it may be said that, while cost is an important consideration, in determining the value or otherwise of litigation, it is not the only relevant factor to be considered and the case has certainly not been made out that

124. Ibid para 5.

125. Ibid para 15 .

126. This was limited to $£ 62,756$. Ibid at para 12 .

127. Ibid para 76 .

128. This view is echoed by M Edwards in his Case Comment on Burkett [2005] JPL 525 at 542 .

129. [2004] EWCA Civ 1342 para 76; see also P Stookes: 'Current Concerns in Environmental Decision Making' [2007] JPL 536-46. 
it should be the paramount one. ${ }^{130}$ There seems to be no good reason, in principle or practice that disputes involving the public interest should be siphoned off into a quasior indeed non-judicial and arguably less visible fora. Indeed it could be said that it is absolutely essential in the public interest, that such cases should be very prominently litigated, and not relegated to what could uncharitably be viewed as some form of legal second division.

The Law Lords also took the view that the Burkett litigation did not result in practical benefit to the claimant, and as the development had already been completed by the time that the case was finally determined, in a narrow sense, this is true. This will often be the case, as the wheels of justice grind exceeding slow, but the development of land once planning permission is given is often swift. However it cannot be overemphasized that the broader issues involved in public interest cases are often of considerable importance in their own right. Burkett itself clarifies number of complex points of law (notably on time limits in judicial review and on costs issues), the elucidation of which will doubtless benefit future litigants in the public interest and environmental spheres and beyond. The claimant herself succeeded in having the issues that concerned her thoroughly examined by the courts: that is, of course, the least that any litigant is entitled to expect, but for the would be public interest litigants is, as will be abundantly clear from the discussion above, far from a given.

Cost concerns were of course amplified by the recognition that, in Burkett they would be paid by the public purse regardless of outcome as the LSC uses scare funds to support claimants in actions against public bodies which must themselves use scare funds to defend the action. ${ }^{131}$ Ultimately though, while the Court recognized that the LSC's lack of funds could have a chilling effect on litigation, it took the view that it was only tasked with applying the current regime - though it did go to the rather unusual lengths of adding an addendum to its judgment to deal specifically with the potential impacts of the status quo on environmental law. The Court in this addendum made specific reference to the EJP study, ${ }^{132}$ highlighting the central role of costs as a barrier to litigation and thus to Aarhus compliance.

The negative implications of the Burkett case were made manifest in the Court of Appeal decision in $R$ (England) $v$ London Borough of Tower Hamlets \& Ors. ${ }^{133}$ The decision is the culmination of a complex trail of litigation attempting to judicially review a grant of planning permission that would result in the demolition of the only canal side loading canopy then extant in London to make way for housing development. The claimant was legally aided and granted permission to apply for judicial review, but his application was dismissed and he was refused permission to appeal. The developers immediately demolished those parts of the site that England sought to protect. The claimant's solicitor was forced to write to the Court of Appeal because counsel would no longer appear as he took the view that legal aid would be unlikely to be forthcoming. The Court, to its credit, allowed the solicitor himself to appear before it. It ultimately dismissed the application for leave to appeal as the matters raised at this point had not been part of the original case. ${ }^{134}$ Furthermore the Court

130. This view is supported in Morgan (below) where at para 46 the Court points out that alternative remedies need to be considered not only for cost but also for efficacy.

131. [2004] EWCA Civ 1342 para 19.

132. See (n 91), above.

133. [2006] EWCA Civ 1742.

134. Separate litigation has been launched on this issue; it will be interesting to see what information based on participation issues arise from this. 
stated that it was difficult to see that the claimant had a continued interest in the outstanding (EU law) issues raised by the case:

... it is unclear to us what interest Mr England has in litigating them once the structure which he was seeking to protect has gone. ... Although judicial review proceedings may often serve to clarify issues of wider importance than the particular concerns of the parties. ... The court decides issues between interested parties, not issues in the abstract. ${ }^{135}$

In making the latter observation, the Court referred to the impact of successful litigation concerning the UK's failure to comply with EU law in $R v$ Bromley $L B C$, ex parte Barker $^{136}$ which ultimately halted the development in question in that case. The Court thought that this served to illustrate the 'potential risks to other interested parties of setting in motion proceedings in a case of this kind. ${ }^{, 137}$ While this may be true, surely England also reveals the dangers in fast development and slow law in the environmental context, as virtually any environmental case can be rendered 'abstract' with much greater speed on the ground than the legal system is able to muster in protecting the public interest in preservation of the environment. The Court in the England case also fails to take the point that, if the claimant is right in interpreting the law, it is surely not disproportionate to require that all the parties abide by it. The Court in England did, however, allude to the cost of funding further litigation and to the possibility of a PCO and in so doing it took the view that England's interest in the case (as someone interested in preserving the environment), raised different considerations from private law interests and that the provision of the Aarhus Convention could be relevant in this regard, though these factors were not found persuasive in the instant case.

$R$ (Buglife) v Thurrock Gateway Development Corporation raises arguably somewhat disquieting issues. It involved judicial review of a grant of planning permission for a distribution hub on a site of national importance for invertebrate life. Sullivan J (as he then was) awarded Buglife a PCO capping potential liability at $£ 10,000$, taking into account the resources of the parties but also the fact that permission had been refused. Interestingly he also ordered, though this was not requested by Thurrock, that potential costs payable to Buglife be capped in the same amount. No reasons were given for this, nor did the parties request them. The Court of Appeal attributed it to what the judge thought just. ${ }^{138}$ If such orders are to be imposed, given not only the inequality of arms issue but also the magnitude of what is at stake for both parties; it would surely be more appropriate not to proceed on the basis of an assumption and furthermore clear reasons should provided as a matter of fairness. Buglife failed in the substantive application but was granted leave to appeal in the public interest. In pursuing this claim, Buglife applied to have its costs coverage extended to the appeal stage and to have Thurrock's cost cap removed. The Court of Appeal broadly followed the approach at first instance and ordered additional costs caps of $£ 10,000$ on each of the parties. While this aspect of Buglife is worrisome, the deeper principle that it reveals is of more profound importance in examining the role of PCOs in addressing Aarhus. Despite the distinctive legal context offered to environmental cases, in particular by the Convention, it remains the case that, according to the Master of the Rolls, approving comments by Waller LJ in $R$ (Compton) $v$ Wiltshire

135. Ibid para 9.

136. [2006] UKHL 52, [2007] 1 AC 470.

137. Ibid para 10 .

138. Ibid para 5 . 
Primary Care Trust ${ }^{139}$ there should be: ' ... no difference in principle between the approach to PCOs in cases which raise environmental issues and the approach in cases which raise other serious issues ... ${ }^{140}$ With respect, this seems to be rather too broad an approach in light of the UK's Aarhus commitments. ${ }^{141}$ Indeed it could be argued that the UK's obligations in this regard already create an interpretative climate that claimants should be entitled to expect will provide a specific influence on the exercise of judicial discretion with regard to costs.

Morgan v Hinton Organics (Wessex) Ltd ${ }^{142}$ raised the issue of costs ${ }^{143}$ once again, though in a different vein. The case concerned the issue of an interim costs award in private nuisance proceedings and whether or not such awards are 'prohibitively expensive' under the Aarhus Convention. The defendants ran a composting site which was subject to a waste management licence (WML). Despite this, smells from the site interfered with the claimants' neighbouring properties, and after a series of complaints to the regulators over a number of years failed to adequately address this, they instituted nuisance proceedings. Initially, in November 2007, the judge being satisfied that the case raised a serious triable issue, an interim injunction was granted. This prohibited the defendants from causing odours affecting the claimants' properties '.. at levels ... perceived by an authorised officer of [either the Agency or the Council] ${ }^{144}$ pending trial, with costs being reserved to the trial judge. The defendants did not appeal against the interim injunction. However, the regulators were unhappy with the terms of the injunction, despite the fact that it closely echoed the WML, and as a result it was discharged in December 2007. The claimants were ordered to pay costs comprising $£ 5132$ for the regulators and $£ 19,190.35$ for the defendants. The claimants had legal expenses insurance of up to $£ 50,000,{ }^{145}$ so the award represented a significant sum in a case where they had demonstrated a serious triable issue, and when set against their total 'fighting fund', surely called into question their ability to litigate the substantive issues. The claimants appealed, arguing that costs should be reserved to the trial judge and that the award was unfair and contravened Aarhus on prohibitive expense. They failed at first instance but subsequently succeeded before Carnwath LJ in April 2008, within a month of the trial date. The application was adjourned for 28 days and the costs order stayed. The claimants succeeded on trial of the substantive issues at first instance. The defendants were given permission to appeal, and this was heard alongside the claimants' appeal against the interim costs order. Carnwath LJ, delivering the Court's judgment, determined that although the claimants' case concerned their individual rights in private nuisance, the extent of the interference in question provided a suitably public element to make it possible to invoke the Aarhus Convention. ${ }^{146}$ In so doing, he took the view that the Aarhus notion of prohibitive expense applied to the totality of litigation costs, including adverse costs orders. However, the value of Morgan in evaluating the impact of the Aarhus Convention is limited because the Convention was not raised in

139. [2008] EWCA Civ 749.

140. Ibid para 17.

141. See (n 92) para 7, 9-11.

142. [2009] EWCA Civ 107, [2009] 2 P\&CR 4.

143. PCOs were only raised before the Court of Appeal, ibid para 35.

144. Ibid para 6. This form of words had been approved in Environment Agency v Biffa Waste Services Limited [2006] EWHC 3495 Admin, para 7.

145. Ibid para 15 .

146. Ibid para 42. 
argument by the claimants before the trial judge which proved decisive. ${ }^{147}$ However, while the Aarhus issue was disposed of in terms of resolving the case in relatively short order, there is a great deal of rather illuminating obiter material in the judgment relating to it. Carnwath $\mathrm{LJ}$ took the view that the Convention did not place compliance obligations on the Court requiring the judge to consider it of his own motion, nor was it a factor that the Court needed to consider on review in order to comply with the Convention. ${ }^{148} \mathrm{He}$ added that claimants needed to argue Aarhus and factually demonstrate the prohibitive nature of the costs in question - merely asserting that there was a risk that costs would be prohibitive was not adequate. ${ }^{149}$ Thus far the judgment did not look at all favourable to the claimants, though it arguably clarifies how future claimants should argue the prohibitive costs issue. However Carnwath LJ considering the costs issue in instant case took the view that it was not right for the judge to award costs when the interim injunction was discharged simply because costs would have been awarded had the initial application failed; ${ }^{150}$ rather the judge should have considered leaving the issue of costs to be determined at trial of the substantive issues. So, although the courts are usually reluctant to interfere with such determination, in this case it was deemed correct to do so and the appeal on the costs issue was allowed, reserving the issue to the trial judge. The Court also had a view on the controversial 'private interest' element in the Cornerhouse test for a PCO; while noting that Goodson had not been overruled, having reviewed subsequent critical case law, it determined that a flexible approach was now intended to be applied to this issue. ${ }^{151}$ At the same time, the Court underlined that, as discussed above, there was no separate approach for PCOs in environmental cases, stating that further development in this area was a matter for legislation or the Rules Committee.

The outcome before the Court of Appeal in Morgan is significant in a number of respects, not least in underlining the limited status enjoyed by the Aarhus Convention as an unincorporated international treaty in UK law ${ }^{152}$ in those areas not covered by Community law (where they are potentially directly effective). This distinction is hugely significant as Carnwath stated that in the latter category of cases ' ... the court's discretion could not be regarded as adequate implementation of the rule against prohibitive costs'. In other cases, however, it acted merely as an aid to interpretation in cases where domestic law intended to give effect to its provisions was ambiguous and, as a result, the normal civil procedure rules on costs ${ }^{153}$ apply. Thus the usual rule that the loser pays the winner's costs remains the norm, subject to the court's discretion to decide to the contrary. ${ }^{154}$

On balance, while it is true to say that PCOs are important in principle, and raise a number of interesting legal issues, and the Cornerhouse requirements as subsequently developed are less restrictive than those that they replaced nonetheless, they ensure, as

147. Ibid paras 49-50.

148. Ibid para 50.

149. Ibid para 51.

150. Ibid para 56.

151. Ibid para 39.

152. Ibid para 50.

153. Part 44, specifically CPR 44.3 .

154. As, for example, in Belize Alliance of Conservation Non-Governmental Organisations $v$ Department of the Environment [2004] UKPC 6 where a costs order was eschewed even though the Alliance lost its appeal on the basis that the case was brought in the public interest. 
the Court intended, ${ }^{155}$ that PCOs will still be imposed only in exceptional cases. ${ }^{156}$ So, although cases have been brought at an increased rate in the wake of Cornerhouse, ${ }^{157}$ success rates have been low. ${ }^{158}$ It is, therefore, probable that PCOs in their current form will play only a peripheral role in facilitating access to litigation, with Legal Aid performing a somewhat more significant (but still necessarily limited) part. ${ }^{159}$ Indeed the fact that the Cornerhouse guidelines are not specifically located in the particular legal context provided for by the Aarhus Convention continues to raise important concerns regarding the effectiveness of PCOs in the environmental sphere, as noted in numerous extra judicial fora including the FPIL ${ }^{160}$ and the Sullivan Report. ${ }^{161}$ As they stand, PCOs do not represent the broader solution to the costs problems that the DEFRA Aarhus Implementation Report seems to suggest. ${ }^{162}$ It is to be hoped that the Jackson review on costs of civil litigation will clarify the role of Aarhus in relation to costs. The Preliminary Report does engage, albeit briefly, with Aarhus issues, opening them up for consultation; ${ }^{163}$ the final report (due in December 2009) should offer more coherent direction for the future.

\section{CONCLUSION}

New human rights based approaches, despite the limitations discussed above, have certainly opened up new opportunities for litigating environmental claims. In so doing, they also generate other effects. They have, for example, recontextualized and reinvigorated discussion of the common law in established areas, notably nuisance. They have also contributed to the development of the concept of fairness in judicial review. This type of litigation has also wrought more diffuse impacts. The enhanced profile that they offer to environmental interests has proved significant in forging greater publicity for 'campaigning cases' than they have previously enjoyed. Campaigning cases may be defined as those brought by an individual, or, more often, an NGO, with the purpose of both litigating a specific issue and of publicizing wider controversies, and many of the foregoing examples of environmental rights based litigation would fall squarely within this category. Such cases tend to be, depending upon one's perspective, opportunistic or pragmatic and creative, employing both broader human rights based and procedural participation routes as available, in conjunction with common law claims. The broader impact of these cases is a significant issue, as there are limits as to what may be achieved by even a successful action in

155. $R$ (Corner House Research) $v$ Secretary of State for Trade and Industry [2005] EWCA Civ 192 at para 72.

156. Sullivan Report (n 92).

157. Ibid 430-431.

158. Ibid. R. Clayton 'Public Interest Litigation, Costs and the Role of Legal Aid' [2006] PL 429 notes that, of the first five contested cases, only one was successful, namely: $R$ (The British Union for the Abolition of Vivisection) v Secretary of State for the Home Department [2006] EWHC 250.

159. Ibid.

160. See (n 90), above.

161. See (n 92), Ch 8 Protective Costs Orders, 18-22.

162. Ibid 28.

163. Civil Litigation Costs Review, Preliminary Report, 08 May $2009<\mathrm{http} / / / \mathrm{www}$.judiciary. gov.uk/about_judiciary/cost-review/preliminary-report.htm> accessed 11 September 2009 Vol $1,334-37$. 
public law. In judicial review, the decision will be retaken, in the correct manner, but the ultimate outcome may be the same. Under the HRA, a declaration of incompatibility may be issued, though the government need not ultimately comply with it. ${ }^{164}$ Given these restrictions, the wider utility of litigation, to gain publicity for a cause, can be a significant strategic consideration.

On the whole though, thus far human rights based approaches in UK law, while they have bred considerable and extremely interesting judicial discussion, have not for the most part greatly extended the legal protection on offer to environmental interests. Protection offered under the ECHR regime is limited by the contingent nature of the rights in question and other limitations inherent in the regime. Changes could be made in this area, short of the controversial introduction of a substantive environmental right, that would improve the effectiveness of the system in respect of environmental interest, for example in opening access to NGOs under Article 34. The Aarhus Convention should, in principle, be a considerable boon for those pursuing environmental claims, but it is only effective in direct proportion to its implementation by signatories. The EU has been rather selective in its approach to date and, this, coupled with the limited status of the Convention in domestic law means that its impacts are at best uneven. In any event, the continued problems posed by the cost of litigation continue to hamper the ability to access Convention rights. The real difficulty lies in the fact that integrating human rights based approaches to the environment into modern law, while much less demanding than according protection to the environment in its own right, is no small thing - success would require a profound change in legal culture predicated on a thoroughgoing societal alteration in the way that we view the environment and our place within it. While recent developments may be regarded as moves in the right direction in mainstreaming the way we address environmental concerns, they represent only small steps when giant leaps are required.

164. S4. 